\title{
Microbial protein and blood parameters of goats fed with licury cake
}

\section{Proteína microbiana e parâmetros sanguíneos de caprinos alimentados com torta de licuri}

\author{
Máikal Souza Borja ${ }^{1 *}$; Ronaldo Lopes Oliveira²; Adriana Regina Bagaldo ${ }^{3}$; Mara \\ Lúcia Albuquerque Pereira ${ }^{4}$; Ricardo Wagner Portela ${ }^{5}$; Analívia Martins Barbosa ${ }^{2}$; \\ Cláudio Vaz Di Mambro Ribeiro²; Gleidson Giordano Pinto Carvalho²
}

\begin{abstract}
The objective of this study was to determine the ideal level of licury cake in the diet of Boer goats through microbial synthesis estimated based on the presence of purine derivatives in the urine and on blood urea and glucose parameters. Twenty uncastrated one-year-old $3 / 4$ Boer goats with an average body weight of $18 \mathrm{~kg}$ were distributed in a completely randomized design. Each animal was confined to a one $\mathrm{m}^{2}$ suspended stall with access to water ad libitum. The diets were formulated in accordance with the NRC (2007), and the ingredients were: 50\% Tifton-85 (Cynodon sp) hay, corn meal, soybean meal, premixed vitamin and mineral supplement, and licury cake. The treatments were: 1) $0 \%$ of the goat's total diet composed of licury cake (DM basis), 2) 15\% of the total diet composed of licury cake, 3) 30\% of the diet composed of licury cake, and 4) $45 \%$ of the diet composed of licury cake. The experiment lasted for 17 days. The first 10 days were used to adapt the animals to the diets and facilities. The inclusion of the licury cake in the goat's diets reduced the levels of blood nitrogen and glucose. Urinary excretion decreased linearly with the inclusion of licury cake in the diet. The inclusion of licury cake in the goat's diets also caused a linear reduction in the excretion of allantoin, xanthine and hypoxanthine and total purine derivative (PD) in urine samples. Based on the microbial protein production and blood parameters of goats fed with licury cake, up to $15 \%$ of the goat diet may be composed of licury cake.
\end{abstract} Key words: Allantoin, hypoxanthine, purine, xanthine, urea, uric acid

\section{Resumo}

O objetivo deste trabalho foi avaliar a síntese de proteína microbiana, ureia e glicose sanguíneas, em caprinos Boer alimentados com níveis de torta de licuri nas dietas. Utilizaram-se 20 caprinos machos não castrados $3 / 4$ Boer com peso vivo médio $18 \mathrm{~kg}$ distribuídos nos quatro tratamentos. Os animais foram mantidos em baias suspensas com um $\mathrm{m}^{2} \mathrm{e}$ água a vontade. As dietas foram formuladas conforme o NRC (2007) e os ingredientes utilizados foram: 50\% feno de Tifton-85 (Cynodon sp), milho moído, farelo de soja, suplemento vitamínico-mineral e torta de licuri. Os tratamentos foram: 1) $0 \%$ de adição (MS\%) de torta de licuri na dieta, 2) 15\% de adição de torta de licuri, 3) 30\% de adição de torta de licuri e 4) $45 \%$ de adição de torta de licuri. O experimento teve a duração de 17 dias, sendo 10 dias de

\footnotetext{
1 Post-graduate in Animal Science, Federal University of Bahia, UFBA, Salvador, BA, Brazil. E-mail: maikalborja@hotmail.com

2 Department of Animal Science, School of Veterinary Medicine and Animal Science, UFBA, Salvador, BA, Brazil. E-mail: ronaldooliveira@ufba.br; analiviabarbosa@hotmail.com; cvdmribeiro@gmail.com; leidsongiordano@yahoo.com.br

3 Center of Agrarian Environmental and Biological Sciences, UFBA, Salvador, BA, Brazil. E-mail: arbagaldo@ufrb.edu.br

4 Department of Basic and Instrumental Studies, UFBA, Salvador, BA, Brazil. E-mail: mara@uesb.br

5 Laboratory of Immunology and Molecular Biology, Health Sciences Institute, UFBA, Salvador, BA, Brazil. E-mail: rwportela@, ufba.br

* Author for correspondence
} 
adaptação dos animais as dietas. A inclusão da torta de licuri na dieta de caprinos promoveu redução nos níveis de ureia e glicose nos caprinos. O volume urinário dos caprinos reduziu de forma linear com a inclusão de torta de licuri na dieta. A inclusão de torta de licuri nas dietas de caprinos promoveu redução linear na excreção de alantoína xantina e hipoxantina e derivados de purinas totais (PD) nas amostras das coletas totais de urina em resposta a inclusão da torta de licuri na dieta. Com base na produção de proteína microbiana e os parâmetros sanguíneos dos caprinos alimentados com torta de licuri, pode-se utilizar até $15 \%$ de inclusão na dieta.

Palavras-chave: Ácido úrico, alantoína, hipoxantina, purinas, uréia, xantina

\section{Introduction}

Raising goats is extremely important for food production (meat and milk), especially in northeastern Brazil where the largest herd in the country is located. However, the goat production industry has low production indices, principally due to poor feeding management.

The use of regional products as goat feed could be a viable method to increase the productivity indices of these herds. This justifies the interest in the study of the use of alternative nutritional supplements that have good nutritional value and a lower cost than traditional supplements (FERREIRA et al., 2009; ARGÔLO et al., 2010).

Licury cake is a regional product that may have good potential as a protein supplement for animal feed. This cake is obtained by pressing the fruit from the licury, Syagrus coronata (Martius) Beccari, a palm tree that is well adapted to semiarid regions. Licury is cultivated for oil production. Licury oil is principally used in the production of cosmetics, soaps and in human and animal foods (BORJA et al., 2010; SILVA et al., 2011).

As a food, licury cake has not been well studied, and its chemical composition is $23.6 \%$ crude protein (CP), $10.1 \%$ ether extract (EE), $51.5 \%$ neutral detergent fiber (NDF), 34.9\% acid detergent fiber (ADF), and $17.3 \%$ lignin, with values based on the dry material (BORJA et al., 2010). Thus, we can characterize the licury cake as a protein source, although it has an elevated NDF value.

The objective this study was to evaluate the effects of licury cake on microbial synthesis (estimated by purine derivatives in the urine) and on blood urea and glucose in Boer goats.

\section{Materials and Methods}

The experiment was carried out in June of 2008 at the School of Veterinary Medicine and Animal Science of the Federal University of Bahia, located in Salvador, Bahia. Salvador is characterized by its humid climate, average annual precipitation of $2098,9 \mathrm{~mm}$, average relative humidity of $81 \%$ and average temperature of $25.3^{\circ} \mathrm{C}$, with a high of $28.1^{\circ} \mathrm{C}$ and a low of $22.5^{\circ} \mathrm{C}$ (CEI, 2010).

The animals were kept individually in $1.0 \times$ $1.0 \mathrm{~m}$ stalls, with suspended floors and water and feeding troughs. Twenty uncastrated male $3 / 4$ Boer goats with an average age of one year and an initial average body weight of $18 \pm 2.2 \mathrm{~kg}$ were assigned to the experimental groups following a completely randomized design. The goats were dewormed and received vaccines in accordance with the local health schedule. As treatments, the goats were fed diets containing $0,15,30$ or $45 \%$ DM licury cake (Syagrus coronata (Martius) Beccari) (Table 1).

The diets were 50:50 forage:concentrate, and Tifron-85 (Cynodon sp) hay was used as the forage. Chemical analyses were performed on the ingredients (Table 2), and the compositions of the diets were later calculated to meet the needs of the animals according to the NRC (2007) (Table 3). The rations were offered twice a day, at $9 \mathrm{am}$ and $4 \mathrm{pm}$, and the total ration was adjusted such that the uneaten food represented $10 \%$ to $20 \%$ of the total offered. Water was provided freely. The duration of the experiment was 17 days, with 10 days of adaptation and 7 days of collection. 
Table 1. The ingredients in the experimental diets.

\begin{tabular}{lcccc}
\hline \multirow{2}{*}{ Items } & \multicolumn{4}{c}{ Licury cake (\%) } \\
\cline { 2 - 4 } & 0 & 15 & 30 & 45 \\
\hline \multirow{2}{*}{ Corn } & 24.3 & 16.5 & 10.6 & 6.2 \\
Soybean meal & 24.2 & 16.1 & 8.1 & 0 \\
Licury cake & 0 & 15.8 & 29.9 & 42.2 \\
Vitamin and mineral supplement $^{1}$ & 1.5 & 1.5 & 1.5 & 1.5 \\
Tifton hay & 50 & 50 & 50 & 50 \\
\hline
\end{tabular}

${ }^{1}$ Nutritional information (per kg of active elements): $120.00 \mathrm{~g}$ calcium, $87.00 \mathrm{~g}$ phosphorus, $147.00 \mathrm{~g}$ sodium; $18.00 \mathrm{~g}$ sulfur, $590.00 \mathrm{mg}$ copper, $40.00 \mathrm{mg}$ cobalt, $20.00 \mathrm{mg}$ chromium, $1800.00 \mathrm{mg}$ iron, $80.00 \mathrm{mg}$ iodine, $1300.00 \mathrm{mg}$ manganese, $15.00 \mathrm{mg}$ selenium, $3800.00 \mathrm{mg}$ zinc, $300.00 \mathrm{mg}$ molybdenum, $870.00 \mathrm{mg}$ maximum fluoride; solubility of phosphorus (P) in citric acid at least $2 \%-95 \%{ }^{2} \%$ of total $\mathrm{N}$.

Source: Elaboration of the authors.

Table 2. Chemical compositions of the ingredients used in the diets.

\begin{tabular}{lccccc}
\hline \multirow{2}{*}{\multicolumn{1}{c}{ Items }} & \multicolumn{5}{c}{ Ingredients } \\
\cline { 2 - 5 } & Corn & $\begin{array}{c}\text { Soybean } \\
\text { meal }\end{array}$ & $\begin{array}{c}\text { Licury } \\
\text { cake }\end{array}$ & $\begin{array}{c}\text { Vitamin and } \\
\text { mineral supplement }\end{array}$ & Hay \\
\hline Dry matter (\%) $_{\text {Mineral matter }}^{1}$ & 88.4 & 90.5 & 95.7 & 100 & 95.6 \\
Organic matter $_{\text {Crude protein }}$ & 1.42 & 5.73 & 7.39 & 100 & 6.23 \\
Ether extract $^{1}$ & 86.9 & 84.8 & 88.3 & 0.00 & 89.4 \\
Neutral detergent fiber $^{1}$ & 6.88 & 42.6 & 23.6 & 0.00 & 7.40 \\
Acid detergent fiber & 3.01 & 2.61 & 10.1 & 0.00 & 0.62 \\
Cellulose $^{1}$ & 11.3 & 10.9 & 51.5 & 0.00 & 80.8 \\
Hemicellulose $^{1}$ & 4.67 & 10.8 & 34.9 & 0.00 & 45.1 \\
Lignin $^{1}$ & 3.59 & 6.88 & 17.6 & 0.00 & 3.59 \\
INND $^{2}$ & 6.66 & 3.53 & 16.7 & 0.00 & 6.66 \\
INND $^{2}$ & 1.08 & 0.85 & 17.3 & 0.00 & 9.20 \\
Non-fiber carbohydrates $^{1}$ & 7.00 & 1.00 & 35.0 & 0.00 & 63.0 \\
\hline
\end{tabular}

$1 \%$ of DM; ${ }^{2} \%$ of total N; INND, insoluble nitrogen in neutral detergent.

Source: Elaboration of the authors.

The dry matter (DM), organic material (OM), crude protein $(\mathrm{CP})$, ether extract $(\mathrm{EE})$, insoluble nitrogen in neutral detergent (INND), and insoluble nitrogen in acid detergent (INAD) were measured in accordance with AOAC guidelines (AOAC, 1990). The measurements of neutral detergent fiber (NDF), acid detergent fiber (ADF), hemicellulose, cellulose and lignin were performed according to the procedure of (VAN SOEST; ROBERTSON; LEWIS, 1991).
The total carbohydrates (TC) were determined using the equation TC $(\%)=100-(\% \mathrm{CP}+$ $\%$ EE +MM) (SNIFFEN et al., 1992). Non-fiber carbohydrates $(\mathrm{A}+\mathrm{B} 1)$ were calculated as follows: NFC $(\%)=100-(\% \mathrm{CP}+\% \mathrm{EE}+\% \mathrm{NDFCP}+$ $\% \mathrm{MM})$, in which $\mathrm{B} 2$ is equivalent to the neutral detergent fiber (NDF). The $\mathrm{C}$ fraction was obtained through the predictive equation for the potential degradation of NDF in bovine feed using CNCPS (Cornell Net Carbohydrate and Protein System): C $(\% \mathrm{TC})=\mathrm{LIG}(\%$ of the NDF $) \times 2.4($ SNIFFEN et al., 1992). 
Table 3. Chemical composition of the diets.

\begin{tabular}{lcccc}
\hline \multirow{2}{*}{ Items } & \multicolumn{4}{c}{ Licury cake (\%) } \\
\cline { 2 - 4 } & 0 & \multicolumn{4}{c}{15} & 30 & 45 \\
\hline Dry matter (\%) & \multicolumn{4}{c}{ Chemical composition (\% DM) } \\
Organic matter & 92.7 & 93.7 & 94.5 & 95.3 \\
Mineral matter $^{1}$ & 86.3 & 86.7 & 87.1 & 87.4 \\
Crude protein $^{1}$ & 6.35 & 6.94 & 7.43 & 7.82 \\
Neutral IND $^{2}$ & 15.7 & 15.4 & 14.9 & 14.1 \\
Acid IND $^{2}$ & 9.00 & 9.00 & 8.00 & 7.00 \\
Ether extract $^{1}$ & 3.00 & 3.00 & 3.00 & 3.00 \\
Neutral detergent fiber $^{1}$ & 1.67 & 2.83 & 3.86 & 4.78 \\
Acid detergent fiber $^{1}$ & 45.9 & 52.2 & 57.9 & 62.9 \\
Lignin $^{1}$ & 25.5 & 30.1 & 34.1 & 37.5 \\
Non-fiber carbohydrates $^{1}$ & 5.07 & 7.65 & 9.95 & 11.9 \\
Metabolizable energy $^{3}$ (Mcal/kg) & 27.1 & 19.9 & 13.7 & 8.63 \\
\hline
\end{tabular}

${ }^{1}$ Values expressed based on dry matter, ${ }^{2}$ Detergent-insoluble nitrogen, ${ }^{3}$ Values estimated according to the NRC (2001).

Source: Elaboration of the authors.

For protein fractionation, the A fraction (nonprotein nitrogen, NPN) was determined as the difference between the total nitrogen and the insoluble nitrogen in trichloroacetic acid (TCA). The insoluble nitrogen in TCA was obtained via incubation of a $500 \mathrm{mg}$ sample with $50 \mathrm{ml}$ of distilled water for 30 minutes with the subsequent addition of $10 \mathrm{ml}$ of TCA at $10 \%$ and incubation for another 30 minutes (LICITRA et al., 1996). The remaining residue was filtered through a paper filter (Whatman, $\mathrm{n}^{\circ}$ 54) and washed with water, yielding the nitrogen content. The true soluble protein in the neutral detergent (fractions B1+B2) was determined as the difference between the insoluble $\mathrm{N}$ in TCA (fraction A), which was determined as described by Pereira and Rossi Júnior (1994). Fraction B3 was calculated as the difference between the insoluble nitrogen in neutral detergent (INND) and the insoluble nitrogen in acid detergent (INAD), both of which were determined by boiling a $500 \mathrm{mg}$ sample in a solution of neutral or acid detergent for an hour, with a subsequent filtration through a crucible and the measurement of nitrogen in the insoluble residue. Fraction $\mathrm{C}$ was considered as the insoluble nitrogen in acid detergent (INAD), according to Licitra, Hernandez and Van Soest (1996).
Blood collection, in which the jugular vein was used as the puncture site and blood was drawn using the Vacutainer system, was performed on the seventh day of collection. Four collections were performed at different times (0, 2, 4 and 6 hours) after the feeding the animals. After the collection, the blood was centrifuged $(2500 \times g$ for 10 minutes $)$ to separate the serum, which was stored $\mathrm{a}-20^{\circ} \mathrm{C}$ for later analysis. Commercial enzymatic colorimetric tests were used for the urea and blood glucose analyses.

All urine collections were performed on the first day of collection. The total collection was performed within a 24 hour period in $5 \mathrm{~L}$ plastic gallons containing $20 \mathrm{ml}$ of $40 \% \mathrm{H}_{2} \mathrm{SO}_{4}$. At the end of the collection, the urine was weighed, homogenized and filtered through gauze, and an aliquot of $10 \%$ of the daily volume was retained. Aliquots of 10 $\mathrm{ml}$ were diluted in $40 \mathrm{ml}$ of $0.036 \mathrm{~N} \mathrm{H}_{2} \mathrm{SO}_{4}$. Acid was included to maintain a $\mathrm{pH}$ below three to avoid the destruction of the urinary purine derivatives of bacteria and uric acid precipitation. The samples were subsequently stored at a temperature of $-20^{\circ} \mathrm{C}$ and then submitted to allantoin, xanthinehypoxanthine and uric acid analyses. The total 
excretion of purine derivatives was calculated as the sum of the quantities of allantoin, uric acid, xanthine and hypoxanthine present in the urine, expressed in $\mathrm{mmol} /$ day.

The equation proposed by Belenguer et al. (2002) for goats was used to estimate the quantity of absorbed purine (X, mmol/ day) as the excretion of purine derivatives $(\mathrm{Y})$ divided by the recuperation rate of purine (0.76).

$$
\mathrm{X}=\mathrm{Y} / 0.76
$$

Assuming that 0.92 is the true digestibility of the purine bases in the duodenum, a 1.97 (mmol of purine bases $/ \mathrm{g} \mathrm{N}$ ) ratio between purine bases (164 mmol/g DM) and an N content of $83.8 \mathrm{mg} / \mathrm{g}$ $\mathrm{DM}$ in the microbial population extracted from the goat's rumen, Belenguer et al. (2002) proposed the following equation:

$$
\begin{aligned}
\mathrm{MN}(\mathrm{g} / \mathrm{d})= & \mathrm{X} /(0.92 \times 1.97) \text { with } \mathrm{MN} \text { being: } \\
& \text { microbial nitrogen. }
\end{aligned}
$$

The experimental design used was completely random with respect to the four treatments. Five animals were included in each treatment group, which received portions of the licury cake in the diets. All of the data were submitted to analysis to identify outliers and to the Shapiro-Wilk test to ensure normality. The data for urea-N and blood glucose were collected at different times and therefore were analyzed using the "Proc Mixed" procedure for repeated measures. In contrast, the data referring to the estimation of the production of microbial protein were analyzed using the "Proc GLM" and "Proc Reg", in which analyses of variance and regression were performed. All of the analyses were performed using the statistical software SAS 1991.

\section{Results and Discussion}

The inclusion of licury cake in the goat's diets caused a linear reduction $(\mathrm{P}<0.05)$ in the levels of blood urea-N (Figure 1). This parameter is positively correlated with the ingestion of nitrogen by the animal (ROSELER et. al., 1993; HENNESSY et al., 1995; VALADARES et al., 1997; MOSCARDINI et al., 1998; CANNAS et al., 1998; WILSON; OVERTON; CLARK, 1998). Thus, the decrease in the levels of urea-N in the blood may be related to the modification of the fractionation of the nitrogen compounds in the diets due to the inclusion of the licury cake (Table 4); the reduction of the protein fraction $\mathrm{A}$ and a rapid degradability and increase of the fractions $\mathrm{B} 3$ and $\mathrm{C}$, which are slow degrading and not degradable, respectively, was observed. This corroborates with the result observed in the diets that contained the licury cake, in which a reduction in the formation of ruminal ammonia and consequent decrease in the nitrogen circulating in the blood (BUN) was observed (Figure 1).

Figure 1. Levels of blood urea-N in goats fed diets with different licury cake contents.

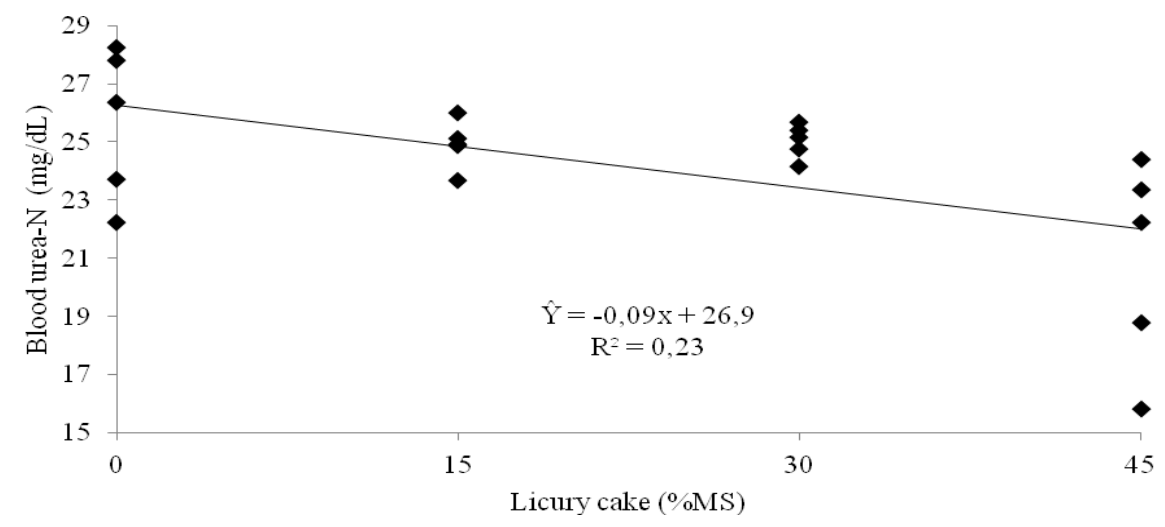

Source: Elaboration of the authors. 
Table 4. Fractionation of carbohydrates and nitrogen compounds in the diets with different licury cake contents.

\begin{tabular}{|c|c|c|c|c|}
\hline \multirow{2}{*}{ Items } & \multicolumn{4}{|c|}{ Licury cake (\%) } \\
\hline & 0 & 15 & 30 & 45 \\
\hline TC (DM\%) & 76.3 & 74.8 & 73.8 & 73.3 \\
\hline \multirow[t]{2}{*}{$\mathrm{TN}(\mathrm{DM} \%)$} & 3.33 & 3.46 & 3.54 & 3.56 \\
\hline & \multicolumn{4}{|c|}{ Fractions of carbohydrates $(\% \mathrm{TC})$} \\
\hline $\mathrm{A}+\mathrm{B} 1$ & 23.6 & 17.5 & 12.5 & 8.6 \\
\hline B2 & 38.1 & 41,7 & 44.9 & 47.7 \\
\hline \multirow[t]{2}{*}{$\mathrm{C}$} & 17.2 & 22 & 26.4 & 30.3 \\
\hline & \multicolumn{4}{|c|}{ Fractions of nitrogen compounds $(\% \mathrm{TN})$} \\
\hline A & 21.16 & 20.44 & 19.55 & 18.47 \\
\hline $\mathrm{B} 1+\mathrm{B} 2$ & 44.93 & 44.77 & 44.86 & 45.17 \\
\hline B3 & 27.51 & 28.21 & 28.85 & 29.45 \\
\hline $\mathrm{C}$ & 4.91 & 5.08 & 5.25 & 5.41 \\
\hline
\end{tabular}

Source: Elaboration of the authors.

Silva et al. (2010) substituted different amounts of soybean meal with detoxified castor bean meal in the diets of sheep. They found that the values of BUN decreased from 34.68 to $23.31 \mathrm{mg} / \mathrm{dL}$. This behavior was attributed to the fact that the product contained less soluble nitrogen fractions, showing that the reduction in the degradability of the protein fraction influences the levels of BUN.

The average values of BUN in the present study were 25.66, 24.90, 25.01 and $20.90 \mathrm{mg} / \mathrm{dL}$ for the $0,15,30$ and $45 \%$ DM licury cake groups, respectively, showing that the protein content in the diets was sufficient to meet the protein demand of the animals. Fonseca et al. (2008) evaluated diets containing $11.5,13.5,15.5$ and $17.5 \%$ crude protein in lactating goats and observed a linear increase in the levels of BUN. The value of blood urea-N observed in the treatment containing $15.5 \%$ crude protein was $22.3 \mathrm{mg} / \mathrm{dL}$, which is close to the values observed in the present study.

A linear decrease $(\mathrm{P}<0.05)$ was verified for the levels of BUN at different times after feeding (Figure 2). The average values found were 24.04, 25.62, 23.86 and $22.97 \mathrm{mg} / \mathrm{dL}$ at 0, 2, 4 and 6 hours after feeding, respectively. Normally, due to the ruminal degradation of dietary protein, elevated concentrations of urea are observed two hours after feeding. A large proportion of the nitrogen compounds that reach the rumen are degraded by microorganisms that release ammonia. During ruminal fermentation, as long as the concentration of ammonia exceeds the level of utilization by the ruminal microorganisms, the same amount is absorbed. Through portal circulations, this ammonia reaches the liver, where it is transformed into urea that, together with the urea produced in the liver from the metabolism of amino acids, constitutes the bulk of the urea plasma. Thus, the absence of the expected elevation of urea plasma two hours after feeding could have been caused by a reduction in the degradability of the proteins in the diets containing the licury cake (Table 4), which translated to a reduction in the formation of ruminal ammonia.

The mechanisms of nitrogen excretion and reutilization may have reduced the blood urea-N at 4 and 6 hours after feeding (Figure 2). López and Stumpf Junior (2000) evaluated the influence of the inclusion of $0,15,30$ and $45 \%$ sorghum grain in the diet of ovines on plasma parameters. A reduction in the levels of urea plasma was observed at postprandial time points. The levels of urea plasma in the animals fed with different portions of sorghum grain were different at 0 and 6 hours after feeding, with average values of 51.9 and $49.5 \mathrm{mg} / 100 \mathrm{ml}$. 
These results were shown to be attributable to the different solubility of the sorghum proteins and carbohydrates.

A linear decrease was observed in the levels of blood glucose $(p<0.05)$ in animals fed with diets containing licury cake (Figure 3); however, these values stayed within the interval considered normal for caprines (40-75 mg/dL) (SWENSON; REECE, 2006). The reduction in the blood glucose levels is correlated with the reduction of NFC levels caused by the inclusion of the licury cake in the goats' diets (Table 4). This fact can be explained by the small amount of NFC in the licury cake relative to the other ingredients (Table 1). NFC is the principal precursor to propionic acid, which is the volatile fatty acid used for glycogenesis by the liver, and it thus serves as the main source of glucose for the ruminants. Thus, the inclusion of licury cake elevated the level of fiber in the diet (Table 3), which favored the production of acetic acid in the ruminal fermentation and reduced the production of propionic acid. A similar reduction of the glucose levels was observed by López and Stumpf Junior (2000) when using sorghum as a feed for sheep, which also reduced the NFC levels in the diets. The reduction of the blood glucose levels was explained by the decreased degradability of the starch from the sorghum in the rumen.

Figure 2. Levels of blood urea in goats fed diets with different licury cake contents at different times after feeding.

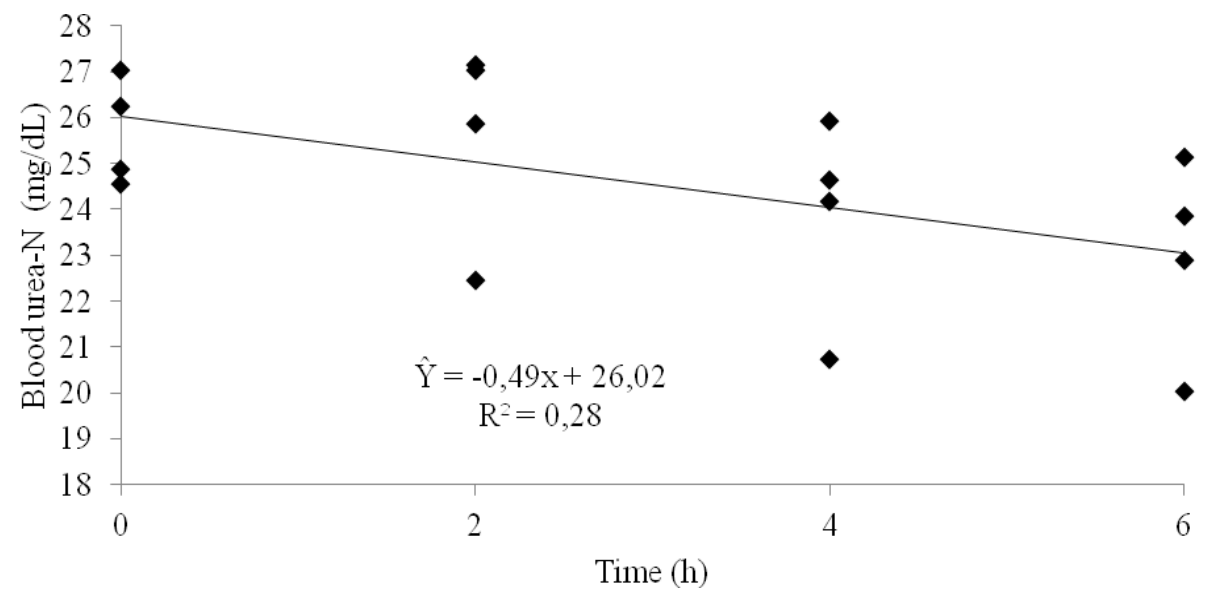

Source: Elaboration of the authors.

The volume of urinary excretion by the caprines (Figure $4 a)$ decreased linearly $(\mathrm{P}<0.05)$ with the inclusion of licury cake in the diet. This decrease was most likely caused by the lower availability of crude protein in the diets (Table 4), which reduced the amount of nitrogen excreted by the caprines. In accordance with the NRC (2001), an increase in the excretion of nitrogen frequently results in increased water demand because water is necessary for metabolic elimination. Fonseca et al. (2008) fed milking goats different levels of $\mathrm{CP}$ in their diets and observed a significant increase $(\mathrm{P}<0.05)$ in the animals'urinary excretion. This can also be explained by the increased need for water when nitrogen excretion is increased. Diets with higher synchrony between the degradability of carbohydrates and proteins in the rumen can improve the utilization of the dietary proteins by the ruminal microorganisms, thus reducing the production of ammonia in the rumen and causing lower levels of blood urea and therefore reducing the nitrogen excreted and the total volume of urinary excretion. Still, with respect 
to the diet composition, the inclusion of licury cake resulted in increased levels of EE (Table 3), which could have favored the adaptation to the hot and humid ambient environment (THI:85) because the EE reduced the caloric increase of the animals (BORJA et al., 2010). Animals under less thermic stress would be expected to excrete less water to achieve heat loss.

Figure 3. Levels of blood glucose in goats fed diets with different licury cake contents.

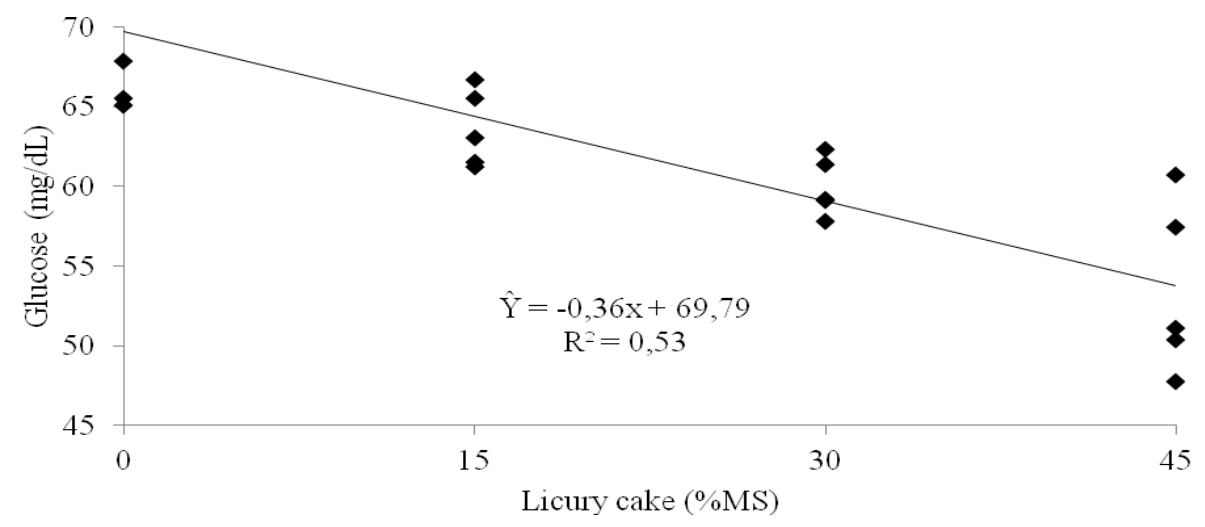

Source: Elaboration of the authors.

A linear reduction $(\mathrm{P}<0.05)$ in the urinary excretion of allantoin and xanthine + hypoxanthine in $\mathrm{mmol} / \mathrm{d}$ (Figures $4 \mathrm{a}$ and $4 \mathrm{~d}$ ) was observed in response to the inclusion of licury cake in the diet, while the excretion of uric acid was not influenced $(\mathrm{P}>0.05)$, with average values of 0.136 $\mathrm{mmol} /$ day. In this study, the reduction of allantoin, xanthine and hypoxanthine excretion may be connected to the reduction of NFC levels and the rapid degradation of the nitrogenous compounds in the diets that included licury cake, which could have caused a reduction in microbial growth due to the lack of rapidly degradable carbohydrates and nitrogen. According to Carvalho et al. (2007), the $\mathrm{A}+\mathrm{B} 1$ fractions provide energy and carbon skeletons for the production of microbial proteins. Due to the substitution of the protein present in soybean meal with that of licury cake, the fraction of non-protein nitrogen (fraction A) was reduced, causing an increase in the time of degradation of the proteins (Table 4) and thus significantly influencing microbial protein synthesis.
A linear reduction in the excretion of purine derivatives was observed in the urine of the caprines with licury cake included in their diets (Figure 4c). This result is explained by the reduction in the urinary excretion of allantoin (Figure $4 b$ ), xanthine and hypoxanthine (Figure $4 \mathrm{~d}$ ). The reduction in the excretion of purine derivatives is indicative of lower microbial production caused by the inclusion of licury cake in the caprines' diets. Of the major nutritional factors, the availability of energy and nitrogen are the main limiting factors in the development of the ruminal microorganisms. Borja et al. (2010) used different portions of licury cake in the caprine diet and did not observe a difference in the consumption of DM with different levels of licury cake. The average daily consumption was 509 $\mathrm{g} \mathrm{DM} /$ day. However, there was a reduction in the consumption of $\mathrm{CP}$ and NFC $(\mathrm{P}<0.05)$ when licury cake was included in the diet. The consumption of $\mathrm{CP}$ and NFC in the treatment without licury cake were $69.4 \mathrm{~g} \mathrm{CP/day}$ and $83.7 \mathrm{~g} \mathrm{NFC/day.} \mathrm{In} \mathrm{the}$ treatment in which licury cake comprised $45 \%$ of the diet, the consumption was $45.7 \mathrm{~g} \mathrm{CP} /$ day and $22.5 \mathrm{~g}$ NFC/day. These factors could have reduced 
the production of microbial proteins and thereby influenced the decrease in the excretion of purine derivatives. With respect to the total excretion of the purine derivatives in the urine, the average percentage of allantoin was from 68 to $77 \%$, while xanthine+hypoxanthine represented from 21 to $30 \%$, and uric acid represented from .08 to $1.6 \%$. In ovines, allantoin makes up $60-80 \%$ of the purine derivatives in the urine, uric acid from $10-30 \%$ and hypoxanthine and xanthine contribute 5-10\%, according to Chen and Gomes (1992). Argôlo et al. (2010) substituted corn with mesquite pod meal in the alimentation of dairy goats and found values similar to those of this study: 65 to $67 \%$ allantoin, .081 to $1.21 \%$ uric acid and 26 to $28 \%$ xanthine and hypoxanthine. Fonseca et al. (2006) provided diets with different levels of CP (11.5, $13.5,15.5$ and $17.5 \%$ ) to dairy goats and found 64 to $76 \%$ allantoin, 16 to $20 \%$ uric acid and 7 to $15 \%$ xanthine and hypoxanthine in the urine. These variations are expected because, according to $\mathrm{Yu}$ et al. (2002), the excretion of allantoin, uric acid, xanthine and hypoxanthine can be affected by the source of dietary protein, the source of energy, the consumption of dry matter (DM), energy, protein, weight, alimentary additives and by species.

Figure 4. a) Volume urinary excretion (L), b) Urinary excretion of allantoin (mmol/day), c) Purine derivatives (mmol/ dl), d) Urinary excretion of xanthine + hypoxanthine (mmol/day).
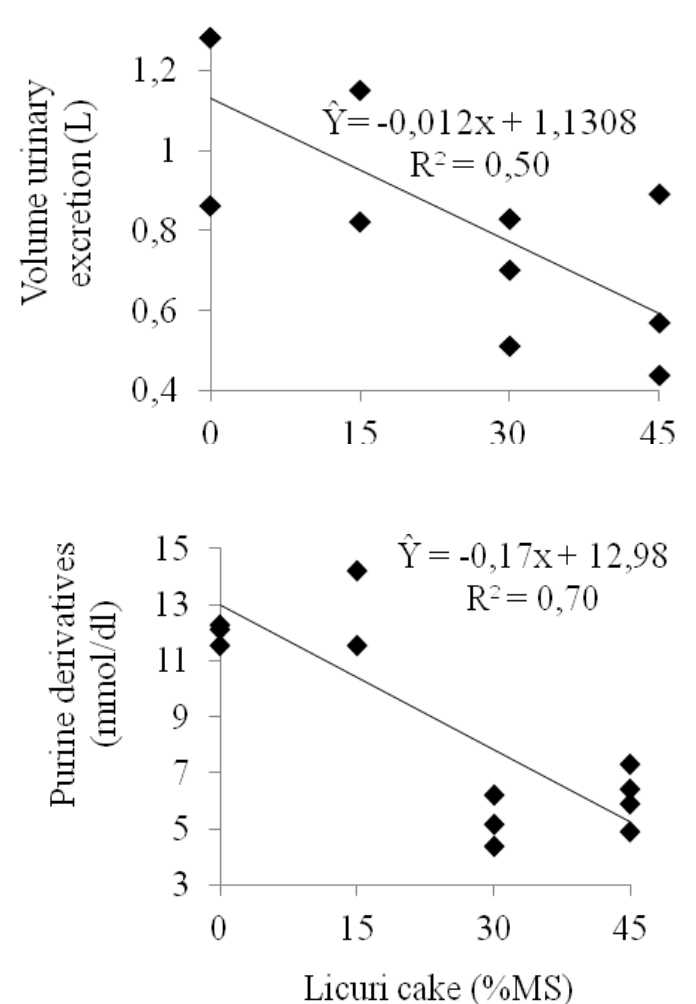

c)

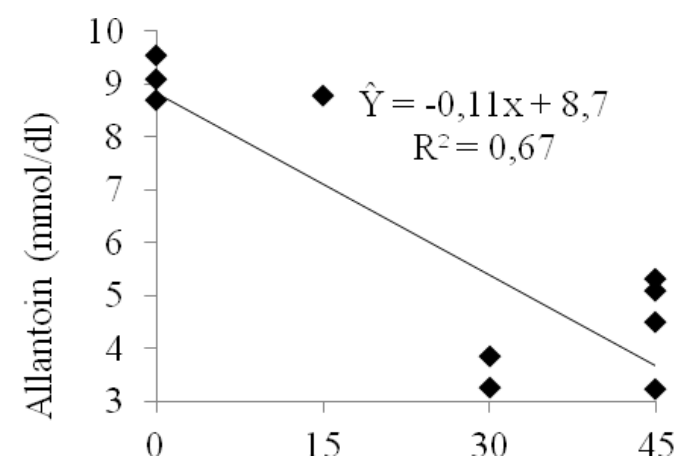

a)

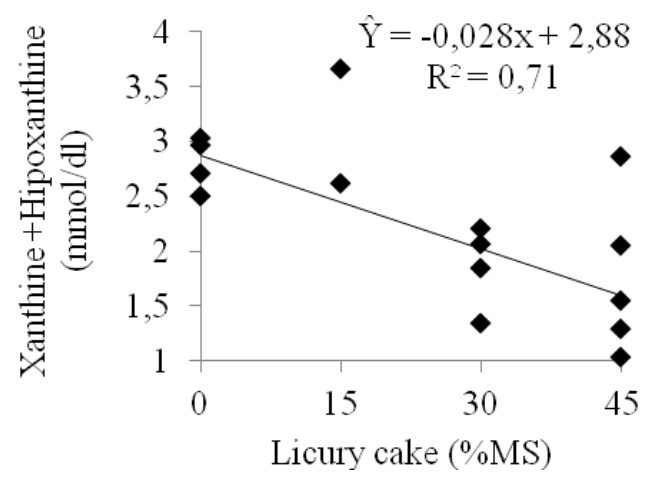

d)

Source: Elaboration of the authors. 
The percentage of uric acid was lower than that of xanthine and hypoxanthine, in contrast to the findings reported by (FONSECA et al. 2006; LINDBERG, 1989; CHEN; MEJIA; ORSKOV, 1995). One common feature between the diet of this experiment and the diet in the experiment conducted by Argôlo et al. (2010) was the lower consumption of NFC by the animals fed with licury cake and those fed with mesquite pod meal, respectively, which caused lower microbial protein production. The lower percentage of uric acid relative to xanthine and hypoxanthine could be explained by the lower metabolic formation of purine derivatives caused by a decrease in xanthine oxidase activity in goats, mainly in the intestine, liver and plasma; this enzyme converts the xanthine into uric acid (BELENGUER et al., 2002).

Significant differences were not found between the values of microbial nitrogen flow in the caprines fed licury cake. The estimated average values for the $0,15,30$ and $45 \%$ licury cake groups were $8.05,6.72,7.00$ and $7.55 \mathrm{mmol} /$ day, respectively. The estimation of the flow of microbial-N depends mainly on the digestibility of the purines absorbed in the duodenum and the ratio between the microbial-N content of the rumen and purines absorbed. This estimate is not absolute and may vary in accordance with the experimental diet (ANDRADE-MONTEMAYOR et al., 2004).

Because licury cake has not been widely studied, its effects need to be evaluated in different species, especially on productive variables like weight gain and milk production. With these data, we will be able to establish its capacity and efficiency as a nutritional supplement for animals.

Based on the results of the production of microbial protein and hematological parameters, licury cake can be used as up to $15 \%$ of the goat's total diet.

\section{References}

ANDRADE-MONTEMAYOR, H.; HERNÁNDEZ, F.; MADRID, J.; MEGÍAS, M. D. Comparison of different models to estimate purine bases absorbed in goats. South African Jounal of Animal Science, Pretória, v. 34, p. 2830, 2004. Supplement 1.

ARGÔLO, L. S.; PEREIRA, M. L. A.; DIAS, J. C. T.; CRUZ, J. D.; DEL REI, A. J.; OLIVEIRA, C. A. S. Mesquite pod meal in diets for lactating goats: ruminal parameters and microbial protein synthesis. Brazilian Journal of Animal Science, Champaign, v. 39, n. 3, p. 541-548, 2010.

ASSOCIATION OF OFFICIAL ANALYTICAL CHEMISTS - AOAC. Official methods of analysis. 15. ed. Washington: AOAC, 1990.

BELENGUER, A.; YANEZ, D.; BALCELLS, J.; OZDEMIR BABER, N. H.; GONZALEZ RONQUILLO, $M$. Urinary excretion of purine derivatives and prediction of rumen microbial outflow in goats. Livestock Production Science, Amsterdam, v. 77, n. 1, p. 127-135, 2002.

BORJA, M. S.; OLIVEIRA, R. L.; RIBEIRO, C. V. D. M.; BAGALDO, A. R.; CARVALHO, G. G. P.; SILVA, T. M.; LIMA, L. S.; BARBOSA, L. P. Effects of feeding licury (Syagrus coronate) cake to growing goats. AsianAustralasian Journal of Animal Science, Champaign, v. 23, n. 11, p. 1436-1444, 2010.

CANNAS, A.; PES, A.; MANCUSO, R.; VODRET, B.; NUDDA, A. Effect of dietary energy and protein concentration on the concentration of milk urea nitrogen in dairy ewes. Journal of Dairy Science, Madison, v. 81, n. 2, p. 499-508, 1998.

CARVALHO, G. G. P.; GARCIA, R.; PIRES, A. J. V.; PEREIRA, O. G.; FERNANDES, F. E. P.; OBEID, J. A.; CARVALHO, B. M. A. Fractionation of carbohydrates in wilted elephant grass silage or with cocoa meal. Brazilian Journal of Animal Science, Viçosa, v. 36, n. 4, p. 10001005, 2007.

CENTER OF STATISTICS AND INFORMATION CEI. Basic information from municipal in Bahia. [S.1.: s.n], 2010. 146 p. (Region metropolitan, n. 6).

CHEN, X. B.; GOMES, M. J. Estimation of microbial protein supply to sheep and cattle based on urinary excretion of purine derivatives: on overview of technical details. Aberdeen: Rowett Research Institute/ International Feed Research Unit, 1992. 21 p. (Occasional publication).

CHEN, X. B.; MEJIA, A. T.; ORSKOV, E. R. Evaluation of the use of the purine derivative: creatinine ratio in spot urine and plasma samples as an index of microbial 
protein supply in ruminants: studies in sheep. Journal of Agricultural Science, Cambridge, v. 125, n. 1, p. 137143, 1995.

FERREIRA, M. A.; SILVA, F. M.; BISPO, S. V.; AZEVEDO, M. Strategies for the supplementation of dairy cows in semiarid Brazil. Brazilian Journal of Animal Science, Viçosa, v. 38, p. 322-329, 2009. Special.

FONSECA, C. E. M.; VALADARES, R. F. D.; VALADARES FILHO, S. C.; LEÃO, M. I.; MARCONDES, M. I. Digestion of the nutrients and nitrogen compounds balance in goats fed with different levels of protein. Brazilian Journal of Veterinary and Animal Science, Belo Horizonte, v. 60, n. 1, p. 192-200, 2008.

FONSECA, C. E. M.; VALADARES, R. F. D.; VALADARES FILHO, S. C.; LEÃO, M. I.; CECON, P. R.; RODRIGUES, M. T.; PINA, D. S.; MARCONDES, M. I.; PAIXÃO, M. L.; ARAÚJO, A. M. Microbial protein synthesis in lactating goats fed diets with increasing levels of dietary protein. Brazilian Journal of Animal Science. Viçosa, v. 35, n. 3, p. 1169-1177, 2006. Supplement.

HENNESSY, D. W.; KOHUN, P. J.; WILLIAMSON, P. J.; BROWN, A. D.; NOLAN, J. V. The effect of nitrogen and protein supplementation on feed intake, growth and digestive function of steers with different Bos indicus, Bos taurus genotypes when fed a low quality grass hay. Australian Journal of Agricutural Research. Collingwood, v. 46, n. 6, p. 1121-1136, 1995.

LICITRA, G.; HERNANDEZ, T. M.; VAN SOEST, P. J. Standardization of procedures for nitrogen fractionation of ruminant feeds. Animal Feed Science Technology, Amsterdam, v. 57, n. 4, p. 347-358, 1996.

LINDBERG, J. E. Nitrogen metabolism and urinary excretion of purines in goat kids. British Journal of Nutrition, London, v. 61, n. 2, p. 309-321, 1989

LÓPEZ, J.; STUMPF JUNIOR, W. Influence of sorghum grain as a source of starch in hay fed sheep. Plasma parameters. Animal Feed Science Technology, Amsterdam, v. 24, n. 4, p. 1183-1190, 2000.

MOSCARDINI, S.; WRIGHT, T. C.; LUIMES, P. H.; McBRIDE, B. W.; SUSMEL, P. Effects of rumenundegradable protein and feed intake on purine derivate and urea nitrogen: comparison with predictions from the cornell net carbohydrate and protein system. Journal of Dairy Science, Madison, v. 81, n. 9, p. 2421-2329, 1998.

NATIONAL RESEARCH COUNCIL - NRC. Nutrient requirements of small ruminants. Washington, DC: National Academy Press, 2007. 281 p.
Nutrient requirements of dairy cattle. 7. ed. Washington. DC: National Academy Press, 2001. 381 p.

PEREIRA, J. R. A; ROSSI JÚNIOR, P. P. Manual of nutritional assessment of nutritional foods. Piracicaba: Foundation of Agrarian Studies Luiz de Queiroz, 1994. $34 \mathrm{p}$.

ROSELER, D. K.; FERGUSON, J. D.; SNIFFEN, C. J.; HERREMA, J. Dietary protein degradability effects on plasma and milk urea nitrogen and milk nonprotein nitrogen in Holstein cows. Journal of Dairy Science, Madison, v. 76, n. 2, p.525-534, 1993.

SILVA, D. C.; ALVES, A. A.; VASCONCELOS, V. R. Metabolism of nitrogen compounds in ovines fed with diets containing detoxified castor meal. Acta Scientiarum Animal Sciences, Maringá, v. 32, n. 2, p. 219-224, 2010.

SILVA, T. M.; OLIVEIRA, R. L.; BARBOSA, L. P.; GARCEZ NETO, A. F.; BAGALDO, A. R.; LANNA, D. P. D.; SILVA, M. C. A.; JESUS, I. B. Preliminary study on meat quality of goats fed levels of licury oil in the diet. Asian-Australasian. Journal of Animal Sciences, Seoul, v. 24, n. 8, p. 1112-1119, 2011.

SNIFFEN, C. J.; O'CONNOR, J. D.; VAN SOEST, P. J.; FOX, D. G.; RUSSELL, J. B. A net carbohydrate and protein system for evaluating cattle diets. Carbohydrate and protein availability. Journal of Animal Science, Champaign, v. 70, n. 11, p. 3562-3577, 1992.

SWENSON, M. J.; REECE, W. O. Dukes-physiology of domestic animals. 12. ed. Rio de Janeiro: Editor Guanabara Koogan S.A., 2006. 38 p.

VALADARES, R. F. D.; GONÇALVES, L. C.; RODRIGUEZ, N. M.; VALADARES FILHO, S. C.; SAMPAIO, I. B. M. Protein levels in cattle diets. 4. Ruminal ammonia n concentration, plasma urea $\mathrm{N}$, and urea and creatinine excretions. Brazilian Journal Animal Science, Viçosa, v. 26, n. 6, p. 1270-1278, 1997.

VAN SOEST, P. J.; ROBERTSON, J. B.; LEWIS, B. A. Symposium: carbohydrate methodology, metabolism, and nutritional implications in dairy cattle. Journal Dairy Science, Champaign, v. 74, n. 10, p. 3583-3597, 1991.

YU, P.; EGAN, A. R.; BOON-EK, L.; LEURY, B. $\mathrm{J}$. Purine derivative excretion and ruminal microbial yield in growing lambs fed raw and dry roasted legume seeds as protein supplements. Animal Feed Science and Technology, Amsterdam, v. 95, n. 1-2, p. 33-48. 2002.

WILSON, R. C.; OVERTON, T. R.; CLARK, J. H. Effects of yucca shidigera extract and soluble protein on performance of cows and concentrations of urea nitrogen in plasma and milk. Journal of Dairy Science, Madison, v. 81, n. 4 , p. $1022-1027,1998$. 
